iSpace: Printed English after Joyce, Shannon, and Derrida

Author(s): Lydia H. Liu

Source: Critical Inquiry, Vol. 32, No. 3 (Spring 2006), pp. 516-550

Published by: The University of Chicago Press

Stable URL: http://www.jstor.org/stable/10.1086/505377

Accessed: 18/11/2014 15:35

Your use of the JSTOR archive indicates your acceptance of the Terms \& Conditions of Use, available at http://www.jstor.org/page/info/about/policies/terms.jsp

JSTOR is a not-for-profit service that helps scholars, researchers, and students discover, use, and build upon a wide range of content in a trusted digital archive. We use information technology and tools to increase productivity and facilitate new forms of scholarship. For more information about JSTOR, please contact support@ jstor.org. 


\title{
iSpace: Printed English after Joyce, Shannon, and Derrida
}

\author{
Lydia H. Liu
}

To begin my essay with a nonword or borderline word is to relive the consequence of manifest entanglements between the literary imagination and technoscience. iSpace is one of many graphic aberrations introduced into English by James Joyce. ${ }^{1}$ There are others, of course- printed signs on paper as well as electronic pulses on the computer screen-that can go anywhere from exuberant nonsense to promised logographical embodiment: "alaphbedic," "televisible," "verbivocovisual," and so on. Joyce scholars have rightly pointed out that literary theory is still catching up with the author of Finnegans Wake, that modernist engineer of a cyberspace avant la lettre of outrageous signs and letter sequences. ${ }^{2}$ Joyce conjured up the printed sign iSpace long before the internet or the iPod. The novelty of his vision and techne of writing never ceases to surprise the generations of readers who have since grown up and experienced the dramatic unfolding of biocybernetic events in their own lives. Like it or not, the lowercase $i$ in iSpace - to be more precise, $i+$ Word-is evolving into a veritable new idiom and ideo-graphein (iPhone, iVision, iTunes, iEnglish, and so on) of our growing electracy that allows us to navigate cyberspace in unforeseen and exciting ways, much like the way that that other ubiquitous prefix works in $e+$ Word. $^{3}$

1. James Joyce, Finnegans Wake (1939; London, 1975), p. 124; hereafter abbreviated FW.

2. Donald F. Theall, for instance, discusses in great detail how Joyce anticipated the age of the microcomputer and its relationship with telecommunication in Beyond the Word: Reconstructing Sense in the Joyce Era of Technology, Culture, and Communication (Toronto, 1995). See also Louis Armand, Technē: James Joyce, Hypertext, and Technology (Prague, 2003); Darren Tofts and Murray McKeich, Memory Trade: A Prehistory of Cyberculture (North Ryde, NSW, 1998); and Thomas Jackson Rice, Joyce, Chaos, and Complexity (Urbana, Ill., 1997).

3. As in the case of acronyms, anagrams, prefixes, and other ideographic functions of the alphabet, the sign $e$-corresponds to the idea embodied in the word electronic or electro- rather 
The purpose of this essay, however, is not to resurrect the ghost of Marshal McLuhan or reiterate the familiar argument about the transformative powers of cybernetic technology and multimedia in modern society that Joyce had intuited and predicted decades ago. I am interested in exploring whether the perceived entanglements between literature and technoscience can promise a new understanding of the nature and function of the phonetic alphabet and alphabetical writing. What insights or implications, if any, can we glean from contemporary biocybernetic developments that may help us rethink literary theory and make it truly relevant to the task of interpreting social life, text, and machine from the ground up, which is to say, from the basic building blocks of literacy? When Roman Jakobson applied Claude Elwood Shannon's information theory to the structural study of language and poetics, for example, he introduced a curious slippage between the syllable and the signal and an isomorphism between meter and frequency. In contrast, Shannon himself had chosen to work on the letters of Printed English while preparing his pathbreaking mathematical theory of communication. His work involved a calculation and comparison of redundancy and entropy rates of English letters and words, including samples from Basic English, Finnegans Wake, and other works, using statistical rather than phonemic parameters. Did Shannon and Jakobson conceive of the phonetic alphabet and its relationship to language differently? How did the slippages occur?

To account for the conceptual gaps between the disciplines and understand what has happened to alphabetical writing since information theory, we may have to begin by reexamining our own preconceived ideas of phonetic inscription and printed English in light of the modernist confluences between literature and biocybernetics. This approach necessarily implicates a reevaluation of the position of poststructuralism with respect to modernism, especially of where Jacques Derrida stands in relation to those confluences and how his work has helped illuminate or obscure certain issues with respect to the printed word in the biocybernetic revolution. The fascinating confluences of ideas among Joyce, Shannon, and Derrida that I am going to explore in my essay are substantial and genuine enough to warrant my

than to the phonemic sequence of the multisyllabic word or prefix it is taken to represent. This applies to email, emuseum, etrade, eBay, eBook, emusic, emedicine, and so on regardless of how one pronounces the letter $e$ in English or some other language.

Ly d a H. LIU is professor of comparative literature and Helmut F. Stern Professor of Chinese Studies at the University of Michigan. She is the author of The Clash of Empires (2004) and Translingual Practice (1995). She is currently finishing a book on literary theory and the biocybernetic imagination. 
argument that Derrida's work is a modernist event in the larger narrative of contemporary technoscience. A belated modernist, to be sure, Derrida found himself coping with the pressures of biocybernetics in the second half of the twentieth century the way that his predecessors had lived their world of telecommunication in the first half as they watched the technological developments with fascination, confusion, attachment, iconoclasm, parody, and, above all, a sense of fetishism for the printed word and typographical design. Like other major contemporary thinkers, Derrida authored books and articles on technology and electronic media, such as Echographies of Television (with Bernard Stiegler), but that alone does not make him a modernist. His belated modernism consists in, among other things, what he has done with typographical inscriptions and spaces as thought experiments (arche-writing, spacing, trace, différance, and so on) and in how he articulated a poetic relationship among those experiments, typographical designs of his works like Glas, and the media of spectrality like film and television. Which is to say, Derrida writes in the wake of Mallarmé, Pound, and Joyce. ${ }^{4}$

But how far will the Derridean project take us in our effort to understand the technology of the universal (English) alphabet as it evolves through the biocybernetic revolution? What does this peculiar alphabet entail for literature, technoscience, cybernetic warfare, and civilization? In Joyce Effects, Derek Attridge questions the familiar reading strategy in literary criticism that grants the theorist privileged access to truth by default. What would happen, asks Attridge, if we were to read Fredric Jameson in the light of Joyce, and not the other way around? Taking this brilliant cue, I think it worthwhile to renegotiate the hermeneutic space between theorist and writer and, if possible, to read Derrida in the light of Joyce and vice versa.

For instance, does iSpace anticipate arche-writing (arche-écriture)? If so, how? In what ways does Derrida's project impinge upon the technology of biocybernetics, which presumes a distinction not so much between writing and speech as between the printed sign and nonprinted sign (under which may be subsumed all forms of handwriting, spoken words, tokens, paintings, traffic lights, and so on)? When the engineers of the universal Turing machine and information theory in the postwar Anglo-American scientific establishment set out to design the universal discrete machine that could "think" and perform intelligent tasks, they uniformly took the printed word or printed letters as their point of departure. That choice was significant, which can make a great deal of difference in how we reassess the technology

4. For his reading of Mallarmé, see Jacques Derrida, "Mallarmé," Acts of Literature, trans. Geoffrey Bennington et al., ed. Derek Attridge (New York, 1992), pp. 110-26. 
of the phonetic alphabet in biocybernetics or its implications for grammatology. When Friedrich A. Kittler states that "the last historical act of writing may well have been the moment when, in the early seventies, Intel engineers laid out some dozen square meters of blueprint paper (64 square meters, in the case of the later 8086) in order to design the hardware architecture of their first integrated microprocessor," he may be exaggerating a little, but it is helpful to keep this perspective in mind as we reflect on the materiality and technology of writing with which arche-writing must also come to terms. ${ }^{5}$

\section{What Would Joyce Have Said to Derrida?}

Being haunted by Joyce is what happens when one is condemned to late arrival on the scene of writing. Insofar as Derrida was writing in the wake of Mallarmé, Pound, and Joyce, the "wake" cannot but introduce a measure of indebtedness and that which is to come in the post-Joycean modernist lineage. It is as if writing were a manner of coping with the ghost of Joyce, settling a score, and discharging an old debt. Derrida was keenly aware of his debt and stated that "Plato's Pharmacy" was a reading of Finnegans Wake. He pointed out that this essay was, in fact, anticipated and "read in advance by Finnegans Wake, in its wake, or its lineage, at the very moment that La Pharmacie de Platon was itself presenting itself as a reading-head or principle of decipherment (in short another software) for a possible understanding of Finnegans Wake." ${ }^{\circ}$ Also the book Glas, according to the author, is "a sort of wake" ("TWJ," p. 150). ${ }^{7}$ The Post Card is likewise "haunted by Joyce, whose funerary statue stands at the centre of the Envois (the visit to the cemetery in Zurich). This haunting invades the book, a shadow on every page, whence the resentment, sincere and acted, always mimed, of the

5. See Friedrich Kittler, "There Is No Software," Stanford Literature Review 9 (Spring 1992): 81. 6. Derrida, "Two Words for Joyce," in Post-structuralist Joyce: Essays from the French, ed. Attridge and Daniel Ferrer (Cambridge, 1984), p. 150; hereafter abbreviated “TWJ." In a footnote to "Plato's Pharmacy," Derrida already points to this connection with Finnegans Wake. See Derrida, Dissemination, trans. Barbara Johnson (Chicago, 1981), p. 88 n. 20.

7. The opening of Glas imitates that of Finnegans Wake by ruminating on the "fall," though with a typical Derridean twist or obsession with etymologies. See Derrida, Glas, trans. John P. Leavey, Jr. and Richard Rand (Lincoln, Nebr., 1986). In The Post Card, Derrida clearly reveals his fascination with what Joyce has written about the "fall." Here is an excerpt from his long commentary:

for that seminar on translation I followed all the Babelian indications in Finnegans Wake and yesterday I wanted to take the plane to Zurich and read out loud sitting on his knees, starting with the beginning (Babel, the fall, and the Finno-Phoenician motif, "the fall (bababadalgh)

[...]. The great fall of the offwall entailed at such short notice the pftjschute of Finnegan [...].

And the italicized Joycean quote goes on and takes up another half page (Derrida, The Post Card: From Socrates to Freud and Beyond, trans. Alan Bass [Chicago, 1987], p. 240). 
signatory" ("TWJ," p. 150). ${ }^{8}$ Derrida confessed that he had been reading Joyce for twenty-five to thirty years by the time he wrote the above in 1982. The curious allusion to the "reading-head" and "software" translates the textual indebtedness into a definitive technological procedure. It encourages us to reflect on the act of reading as decoding a form of technologized inscription on the magnetic tape of Joyce's "hypermnesic machine" ("TWJ," p. 147). The machine then becomes the material condition of arche-writing and its modernist ethos. Following this trajectory of indebtedness, can we perhaps read iSpace and other typographic experiments in Finnegans Wake as a prefiguring or a prior recording of the Derridean project?

The thought of a "hypermnesic machine" designed to anticipate all one can possibly say in a language and exhaust every conceivable combination of verbal elements is a terrifying one. Derrida's admiring resentment toward Joyce is rooted in his modernist ambivalences about the increasing dominance of prosthetic machines in human affairs. In "Two Words for Joyce," he offers an interesting speculation upon the implications of Finnegans Wake in anticipation of computer technology. He writes:

He [Joyce] talks about it often enough for there to be no simple confusion between him and a sadistic demiurge, setting up a hypermnesic machine, there in advance, decades in advance, to compute you, control you, forbid you the slightest inaugural syllable because you can say nothing that is not programmed on this 1oooth generation computerUlysses, Finnegans Wake-beside which the current technology of our computers and our micro-computerified archives and our translating machines remains a bricolage of a prehistoric child's toys. And above all its mechanisms are of a slowness incommensurable with the quasi-infinite speed of the movements on Joyce's cables. How could you calculate the speed with which a mark, a marked piece of information, is placed in contact with another in the same word or from one end of the book to the other? For example, at what speed is the Babelian theme or the word "Babel," in each of their components (but how could you count them?), co-ordinated with all the phonemes, semes, mythemes, etc. of Finnegans Wake? Counting these connections, calculating the speed of these communications, would be impossible, at least de facto, so long as we have not constructed the machine capable of integrating all the variables, all the quantitative or qualitative factors. This won't happen tomorrow, and in any case this machine would only be the double or the simulation of the event "Joyce," the name of Joyce, the signed work, the Joyce software today, joyceware. [“TWJ," pp. 147-48]

8. He refers here to a visit to Joyce's tomb on 20 June 1978. See Derrida, The Post Card, p. 148. 
A sense of absolute belatedness and inadequacy is the defining tone of the ambivalent sentiments being expressed here. What is "joyceware" if it is not the ultimate homage Derrida or anyone could pay to Joyce? And what would Joyce have said to the author in response? For one thing, he would certainly have concurred with the idea that Finnegans Wake was a feat of engineering that was intended to surpass the most advanced computer that has ever existed or will ever exist. Donald F. Theall argues, for instance, that Joyce approached language (writing) as a mathematical structure and an engineering problem. In the course of writing Finnegans Wake, then known as the Work in Progress, the ambitious novelist wrote to his patron Harriet Shaw Weaver that this book would prove him to be "the greatest engineer," an interesting claim put forth by someone who was prepared to devote seventeen years of his life (1922-1939) to this single work. ${ }^{9}$ Theall outlines three aspects of Joyce's claim that go beyond mere metaphor. First, Joyce conceived of his work as a kind of a machine. Second, "the Wake encompasses many aspects of engineering: chemistry, mechanics, mathematics, geography, and strategic planning." Third, Joyce came to realize the extent to which the activities of arts and communication in his period "involved new modes of social organization and of technological production, reproduction, and distribution" ("HEE," p. 134). Here, I would like to add a fourth dimension to Theall's perceptive reading, namely, Joyce's anticipatory contribution to communication engineering itself. This consists in his effort to bring the statistical properties of letter sequences and spaces among words and nonwords to light. His act of engineering involved subjecting the statistical mechanism of alphabetical writing to an elaborate literary experiment two decades in advance of Shannon's experiment with the statistical models of Printed English. In fact, the founder of information theory himself has mentioned using the statistical properties of Finnegans Wake in the course of conceptualizing his mathematical theory of communication. Moreover, it was precisely during the time interval between Joyce and Shannon that communication engineering became a statistical science and a branch of statistical mechanics. ${ }^{10}$ This aspect of cybernetic developments is discussed in a later section.

9. Quoted in Theall, "The Hieroglyphs of Engined Egypsians: Machines, Media, and Modes of Communication in Finnegans Wake," Joyce Studies Annual (1991): 132; hereafter abbreviated "HEE." Theall excerpts the following from Joyce's correspondence: "In the meantime, I am preparing for it ... by pulling down more earthwork. The gangs are now hammering on all sides. It is a bewildering business. I want to do as much as I can before the execution. Complications to right of me, complications to left of me, complex on the page before me, perplex in the pen beside me, duplex in the meandering eyes of me. And from time to time I lie back and listen to my hair growing white" ("HEE," pp. 134-35).

10. See Norbert Wiener, Cybernetics, or Control and Communication in the Animal and the Machine, 2d ed. (1948; New York, 1961), pp. 8-10. 
No doubt, the idea of a "hypermnesic machine" is a brilliant one and works extremely well with Finnegans Wake. ${ }^{11}$ But where Joyce would disagree with Derrida is that his machine is programmed with a coding system that is "nat language at any sinse of the world" (FW, p. 83). To expect a computer to think in terms of syllables or recognize things like phonemes, semes, mythemes, and so on is not so much to make a demand on its speed and hardware as it is to ask the machine to be a linguist like Roman Jakobson. Derrida's slip of the tongue is intriguing. Could it have been an unconscious reaffirmation of the structural theory of language that he had deconstructed elsewhere? Whatever assumptions he may have held about telecommunication when proposing the trope of "joyceware," there will not be phonemes and verbal utterances in either the hardware or software of a computer. The computer obeys symbolic logic alone and works with numbers and letters that do not stand for syllables or phonemes in natural languages. I strongly doubt, therefore, that "joyceware"-Derrida's smart parody in the spirit of the "wake" — can ever be made to operate in linguistic terms, pace Jakobson. By the same token, if a reader claims that he or she can identify phonemes, semes, and mythemes in Finnegans Wake, it could only mean that he or she has construed these "linguistic facts" on the basis of the printed text in the reading process.

Garrett Stewart brings this cognitive process of reception to our attention in his reading of the pressures of "pronunciation upon script" in Joyce's text. ${ }^{12}$ Stewart's reading, however, forgets to take the figure of the "hypermnesic machine" into account as he ponders the unexpected eruption of the phoneme in Derrida's interpretation of Finnegans Wake. For he takes this slip of the tongue to be the philosopher's unguarded reaffirmation of the priority of the phonic in Finnegans Wake when it could have been understood as a misguided phonocentric figuring of the computer. Stewart argues that "though no one, even to oneself, can of course say two sounds at once, even though prompted by a single letter, any of us is able to register, by phonic rather than graphic deferral, what amounts to an aural rather than scriptive palimpsest, an overlapping of phonemes."13 It seems to me that the point is not whether the reader can register polyphony in his or her mind's ear but how the written letter is able to sustain the illusion of human voice or polyphony in silent reading at all, much less orchestrate the play of meanings across different semiotic systems.

With respect to the figure of the machine in Finnegans Wake, Theall has

11. Elsewhere, Derrida gives an analysis of the figure of the machine in Ulysses. See Derrida, "Ulysses Gramophone: Hear Say Yes in Joyce," Acts of Literature, pp. 253-309.

12. Garrett Stewart, Reading Voices: Literature and the Phonotext (Berkeley, 1990), p. 245.

13. Ibid., p. 246. 
suggested three kinds of communicating systems that occupied a role of particular relevance for Joyce. These are "traditional sign systems (hieroglyphs, alphabets, icons, drawings); technologically mediated modes of reproduction (print, telephone, film, television); and crafted modes of popular expression dependent either on the traditional or the technologically mediated (riddles, comics)." These systems coexist in one "integrated semiotic" machine that is grounded not so much in the logos as in gesture ("HEE," p. 151). "The grounding of communication in gesture is underlined" by a quote that Joyce lifted and modified "from [Marcel] Jousse on the opening of the Gospel of St. John: 'In the beginning was the Word ..."': "In the beginning was the gest he jousstly says" (FW, p. 468). Theall explains that "gesture (gest, F. geste = gesture) is linked with the mechanics of humor (i.e., jest) and to telling a tale (gest as a feat and a tale or romance)" ("HEE," p. 137). Samuel Beckett's early comments on Joyce's Work in Progress demonstrate a superior sense of the peculiar movement of alphabetical gestures when he remarks:

This writing that you find so obscure is a quintessential extraction of language and painting and gesture, with all the inevitable clarity of the old inarticulation. Here is the savage economy of hieroglyphics. Here words are not the polite contortions of 2oth century printer's ink. They are alive. They elbow their way on to the page, and glow and blaze and fade and disappear. ${ }^{14}$

Not unlike elementary mechanical systems for communications such as signals and flashing lights, the dancing of printed "words of silent power" on the page of the Wake embodies what I term the ideographic movement of the phonetic alphabet ( $F W, \mathrm{p} .345)$.

For instance, Derrida indulges in the etymological and semantic contortions of the word chute (the "fall"), which begins Finnegans Wake, a reading that Joyce seems to deliberately frustrate by inserting a nonsense 100-character string in the opening chapter of Finnegans Wake: "The fall (bababadalgharaghtakamminarronnkonnbronntonnerronntuonnthunntro varrhounawnskawntoohoohoordenenthurnuk!) of a once wallstrait oldparr is retaled early in bed and later on life down through all christian minstrelsy" (FW, p. 3). ${ }^{15}$ "Joyceware," the language game, is the effect of

14. Samuel Beckett, "Dante ... Bruno. Vico.. Joyce," in Beckett et al., Our Exagmination Round His Factification for Incamination of Work in Progress (1929; New York, 1979), pp. 16-17.

15. As I suggested in footnote 7, Derrida's language in the opening of Glas is an imitation of Finnegans Wake. He writes: "Of the remain(s), after all, there are, always, overlapping each other, two functions. The first assures, guards, assimilates, interiorizes, idealizes, relieves the fall [chute] into the monument. There the fall maintains, embalms, and mummifies itself, monumemorizes and names itself-falls (to the tomb(stone)) [tomb]. Therefore, but as a fall, it erects itself there," 
an elaborate graphic choreography that mobilizes printed words on a twodimensional stage or what Joyce terms "paperspace" (FW, p. 115). The nonsense letter sequence within the parentheses precipitates a horizontal tumbling of the letters to simulate the fiction of an action. Even if the reader is tempted to pronounce the impossible syllable sequence, there will be phonic elements but no phonemes to mark in the text. Marking the phoneme means closing off the boundaries of a single linguistic system (English, German, French, or other) relative to which a phoneme is taken to function, and this is precisely the kind of linguistic sanctuary Joyce refuses to grant the reader. Throughout Joyce's text, we discover cross-linguistic alphabetical letters, units of letters, and graphic symbols with spaces around them, as well as two-dimensional surfaces, typographical positions, and so on. Below is how Finnegans Wake allegorizes the history of inscription for its own benefit:

A bone, a pebble, a ramskin; chip them, chap them, cut them up allways; leave them to terracook in the muttheringpot: and Gutenmorg with his cromagnom charter, tintingfast and great primer must once for omniboss step rubrickredd out of the wordpress else is there no virtue more in alcohoran. For that (the rapt one warns) is what papyr is meed of, made of, hides and hints and misses in prints. Till ye finally (though not yet endlike) meet with the acquaintance of Mister Typus, Mistress Tope and all the little typtopies. Fillstup. So you need hardly spell me how every word will be bound over to carry three score and ten toptypsical readings throughout the book of Doublends Jined (may his forehead be darkened with mud who would sunder!) till Daleth, mahomahouma, who oped it closeth thereof the. Dor. [FW, p. 20]

This mini mock history of literacy, print, and civilization appears to give the illusion of a voice discoursing in puns and nonsense words whereas what is really happening in what Shannon would call a time series is the movement of a reading-head avant la lettre or our eyes doing the visual scanning of "Typus," "Tope," "typtopies," "toptypsical," "wordpress," "prints," “.”, and so on in rapid typographical procession. The Latin word typus, which derives from the Greek typos, suggests a "mark," "impression," or "impressed form" on a prepared surface like ramskin or papyrus. This manner of creating surface "words" or "verbivocovisual" prints cannot but make a new demand on the movement of arche-writing, submitting it to the test of the Joycean wordpress and the materiality of its "archetypt" ( $F W$, p. 263).

and so on (Derrida, Glas, p. 1). He goes on in this vein through the next page. In The Post Card, Derrida speaks frankly about his desire to imitate Joyce: "Never have I imitated anyone so irresistibly" (p. 142). 
One of the things we may learn from a Joycean sign like iSpace is to acknowledge the phonetic alphabet as a system of actual or potential ideograms. The notion of ideogram (ideo + gram or N-gram) is to be understood in the sense of Gedankenschrift or "thought writing," including numerals, punctuation marks, unutterable signs, and other graphic marks, not to be confused with pictographs or pictures. And such is how the sign iSpace makes its appearance in Finnegans Wake:

These paper wounds, four in type, were gradually and correctly understood to mean stop, please stop, do please stop, and O do please stop respectively, and following up their one true clue, the circumflexuous wall of a singleminded men's asylum, accentuated by bi tso fb rok engl a ssan dspl itch ina, _— Yard inquiries pointed out $\longrightarrow>$ that they ad bîn "provoked” ay $\Lambda$ fork, of à grave Brofèsor; àth é’s Brèak-fast-table; ; acùtely profeššionally piquéd, to = introdùce a notion of time [ùpon à plane (?) sù' ' fàçe'e'] by pùnct! ingh oles (sic) in iSpace?! [FW, p. 124]

The double entendre of writing and wounding in the quote is carried out through the movement of graphic marks that visualize the "bits of broken glass and split china" by mangling the word spaces as "bi tso fb rok engl a ssan dspl itch ina." The idea of making holes in iSpace literalizes the act of punctuation and writing as a source of paper wounds. This passage throws the reader into the mise en abîme of graphic spacing, punctuation marks, irregular types, and letter sequences.

Eugene Jolas, who was the founder of the avant-garde journal Transition and who was responsible for publishing fragments of Joyce's Work in Progress, immediately grasped the significance of this iconoclastic act when he declared in 1929 that "the real metaphysical problem today is the word." 16 Graphic spacing is taken as an assault on logocentrism as it dissolves the familiar word and becomes itself the originary act of writing in iSpace. The latter certainly anticipates the Derridean notion of spacing and différance for grammatology; but, more appropriately, iSpace is about the ideographic prolepsis of modern technology, ranging from cybernetics (the punning on "plane" in the quote puts us in mind of Norbert Wiener's anti-aircraft feedback loop) to the internet, bearing the news of the iPhone, iVision, iTunes, iLove, and iPolitics of the future. Most symptomatic of all is the appearance of iEnglish itself on the internet. The crux of the matter is not whether the letter $i$ means "intelligent," "information," "internet," or "imaginary" or simply represents an inverted exclamation mark that has no corresponding phonetic equivalent in the spoken language but rather that the

16. Eugene Jolas, “The Revolution of Language and James Joyce," in Beckett et al., Our Exagmination Round His Factification for Incamination of Work in Progress, p. 79. 
ideographic structure of $\mathrm{i}+$ Word (or even $\mathrm{i}+$ word) provides the sole semantic guarantor for any or all of the meanings one can possibly attribute to the letter $i$.

This semantic indeterminancy is bound to raise the cognitive question of how the eyes and brains of a reader pick up alphabetical letters and words visually in the act of reading. It is a subject for the specialist in neuropsychology and related sciences but should be of some interest to literary scholars as well. When Jakobson provided his analysis of a linguistic disorder known as atactic, which is a form of aphasia, he identified the following cognitive trait in word recognition as pathology. A patient who suffers from atactic, according to him, has "only an integral, indissolvable image of any familiar word, and all other sound-sequences are either alien and inscrutable to him, or he merges them into familiar words by disregarding their phonetic deviations." 17 Although the "indissolvable image of any familiar word" here applies to speech events in the context of Jakobson's discussion, the pathological type he singles out has interesting implications for visual word recognition as well. If the inability to distinguish phonemes as the minimal entities of speech events is pathological, what do we make of the ordinary reader's tendency to fix on the "indissolvable" image of a word as an integral, scriptic unity on the page? Is it normal or pathological? Recent studies in experimental psychology have provided compelling evidence to show that the "word shape" - or information in the shape of an entire word-plays an important role in reading or "visual word recognition." 18

17. Roman Jakobson, “Two Aspects of Language and Two Types of Aphasic Disturbances," Language in Literature, trans. Stephen Rudy et al., ed. Krystyna Pomorska and Rudy (Cambridge, Mass., 1987), p. 108.

18. I thank David Lurie for calling my attention to the ongoing discussions on randomized letters in alphabetical writing. Investigation into the randomizing of letters in a nonword or what researchers call transposed-letter confusability casts an interesting light on the problem of visual word recognition. See Manuel Perea and Stephen J. Lupker, "Does Jugde activate COURT? Transposed-Letter Confusability Effects in Masked Associative Priming," Memory and Cognition 31, no. 6 (2003): 829-41 and "Transposed-Letter Confusability Effects in Masked Form Priming," in Masked Priming: The State of the Art, ed. Sachiko Kinoshita and Lupker (Hove, England, 2003), pp. 97-120. Although we are better at guessing a word than guessing individual letters in the word (Word Superiority Effect), the fact that word shape can be disrupted by the transpositions or randomizing of letters also raises the issue of where the individual letter stands in relation to word shapes. For a recent discussion of this problem, see Denis G. Pelli, Bart Farell, and Deborah C. Moore, "The Remarkable Inefficiency of Word Recognition," Nature, 12 June 2003, pp. 752-56. For related studies, see Kate Mayall, Glyn W. Humphreys, and Andrew Olson, "Disruption to Word or Letter Processing? The Origins of Case-Mixing Effects," Journal of Experimental Psychology 23, no. 5 (1997): 1275-86. See also Richard Shillcock, T. Mark Ellison, and Padraic Monaghan, "EyeFixation Behaviour, Lexical Storage, and Visual Word Recognition in a Split Processing Model," Psychological Review 107, no. 4 (2000): 824-51; Sally Andrews, "Lexical Retrieval and Selection Processes: Effects of Transposed-Letter Confusability," Journal of Memory and Language, 35, no. 6 (1996): 775-800; Leo X. McCusker, Philip B. Gough, and Randolph G. Bias, "Word Recognition Inside Out and Outside In," Journal of Experimental Psychology 7, no. 3 (1981): 538-51; Alice F. Healy, 
As it happens, people do not read each letter in a word individually except in a relatively rare condition following brain injury known as word-form dyslexia. ${ }^{19}$

For all his phonocentric biases, even Saussure took notice of the propensity of alphabetical writing to slide in the direction of ideographical aberrations. According to the notes of his student Émile Constantin, Saussure remarked in his 1910 lecture on orthography: "One must not forget that the written word eventually becomes, through force of habit, an ideographic sign [un signe idéographique]. The word has a global value $<$ independently of the letters of which it is formed $>$. We read in two ways: spelling out unfamiliar words and reading familiar words at a glance."20 Whether the truth of his observation can fully be corroborated by cognitive sciences or not, it is interesting to note that Saussure's discovery of the "global value of the word" tending toward ideography appears to contradict his well-established notion of writing as a visual representation of the spoken language just as sharply as it disputes Jakobson's famous diagnosis of atactic. To what extent this remarkable insight might also be connected with his unfavorable view of spelling pronunciations in speech where "visual images lead to wrong pronunciations" can, of course, be debated. ${ }^{21}$ His mention of the force of habit seems to resonate with a degenerate view of alphabetical writing Derrida has analyzed in Of Grammatology. ${ }^{22}$ Whether Derrida became aware of Saussure's insight about the global value of the phonetic word after the publication of Constantin's notebooks in 1993 is unclear; perhaps it would not have mattered to him since what he said about Hegel could have applied to Saussure just as well. Hegel, as we know, had an intuitive grasp of the hieroglyphic potential of alphabetical writing, which led Derrida to call him the last philosopher of the book and the first thinker of writing. ${ }^{23}$ Reflecting on the acquisition of literacy, Hegel had written that "acquired habit later also suppresses the specificity of alphabetic writing, which consists in seeming to be, in the interest of sight, a detour [Umweg] through

\footnotetext{
"Detection Errors on the Word The: Evidence for Reading Units Larger Than Letters," Journal of Experimental Psychology2, no. 2 (1976): 235-42; and Gerald M. Reicher, "Perceptual Recognition as a Function of Meaningfulness of Stimulus Material," Journal of Experimental Psychology 81, no. 2 (1969): 275-80.

19. See Elizabeth K. Warrington and Tim Shallice, "Word-Form Dyslexia," Brain 103 (Mar. 1980): 99-112.

20. Ferdinand de Saussure, Troisième Cours de linguistique générale (1910-1911) d'après les cahiers d'Émile Constantin/Saussure's Third Course of Lectures on General Linguistics (1910-1911) from the Notebooks of Émile Constantin, trans. Roy Harris, ed. Eisuke Komatsu (Oxford, 1993), p. 64; my emphasis.

21. Saussure, Course in General Linguistics, trans. Wade Baskin (New York, 1966), p. 31.

22. See Derrida, Of Grammatology, trans. Gayatri Chakravorty Spivak (Baltimore, 1976), p. 31.

23. See ibid., p. 26.
} 
hearing to arrive at representations, and makes it into a hieroglyphic script for $u$ s, such that in using it, we do not need to have present to our consciousness the mediation of sounds." ${ }^{24}$ Hegel attributed the ideographical tendencies of the phonetic alphabet to the force of habit, a kind of degenerative aberration. But the fact that both Hegel and Saussure confronted the problem of visual word recognition should be taken seriously because there is much more to their insights about the ideographic potential of alphabetic writing than the metaphysical defense they shore up against writing in general.

The intractability of the ideographic within the system of alphabetical writing can further be interrogated by reexamining the important role the ideographic sign played between modernism and science in the early twentieth century. W. J. T. Mitchell has shown that "Wittgenstein's use of the hieroglyphic as a model for the picture theory of language and Ezra Pound's fascination with Chinese picture writing as a model for the poetic image might be taken as marking the boundaries of this role." ${ }^{25}$ The idea of the ideogram, interpreted by Pound and others as picture-writing, is undoubtedly intended to help defamiliarize alphabetic writing for the purpose of vorticist poetry. But there is another function, with broader contemporary implications, suggesting that the ideogram also concretizes an interface between the prosthetic machine and the human mind, as Pound puts it: "Man is - the sensitive physical part of him-a mechanism, for the purpose of our further discussion a mechanism rather like an electric appliance, switches, wires, etc. ... In the telegraph we have a charged surface . . . attracting to it, or registering movements in the invisible ether." ${ }^{26}$ In the manuscript from which Pound constructed his revised version of Fenollosa's essay, the latter refers to "radiation" and "coronal" harmonies that

24. Quoted in ibid., p. 25; my emphasis.

25. W. J. T. Mitchell, Iconology: Image, Text, and Ideology (Chicago, 1986), p. 29.

26. Ezra Pound, The Spirit of Romance (New York, 1968), pp. 92, 93. As early as 1886, Charles Howard Hinton had presented a theory of the invisible ether that anticipated this modernist view of machine. Conceiving the ether medium as a cosmic phonograph, Hinton wrote:

For suppose the æther, instead of being perfectly smooth, to be corrugated, and to have all manner of definite marks and furrows. Then the earth, coming in its course round the sun on this corrugated surface, would behave exactly like the phonograph behaves.

In the case of the phonograph the indented metal sheet is moved past the metal point

attached to the membrane. In the case of the earth it is the indented æther which remains still while the material earth slips along it. Corresponding to each of the marks in the æther there would be a movement of matter, and the consistency and laws of the movements of matter would depend on the predetermined disposition of the furrows and indentations of the solid surface along which it slips.

(Charles Howard Hinton, Scientific Romances [London, 1886], pp. 196-97) 
can be produced by an ideogram. ${ }^{27}$ Pound found this conception particularly amenable to his own theory of radioactive images and went so far as to assert that the "true science, true thinking is ideogrammic in the sense that the general is composed of definite particulars known directly by the thinker." ${ }^{28}$ This sounds like a cryptic allusion to mathematical symbols and their implications for thinking the finite and infinite, and I will address mathematical thinking in relation to Shannon's twenty-seven-letter English alphabet in the next section.

Whereas Wittgenstein focused his attention on the activity of semiotic work and language games, Pound interpreted the ideogram as an aspiration toward an immediacy of knowledge that no spoken word could possibly mediate for science. ${ }^{29}$ This understanding was based on a theory of image he put forward in his 1914 "Vorticism" manifesto in which he argues that an image is real because "we know it directly" and "every concept, every emotion, presents itself to the vivid consciousness in some primary form." He further contends that art and science have many things in common since "the imagiste's images have a variable significance, like the signs $a, b$, and $x$ in algebra" and that "any mind that is worth calling a mind must have needs beyond the existing categories of language, just as a painter must have pigments or shades more numerous than the existing names of the colours." ${ }^{30}$ It is not that the phonic aspect of alphabetic writing had lost its valence for Pound or for other avant-garde writers but rather that, under the regimen of prosthetic machines (gramophone, telegraph, telephone, typewriter, radio, and so on), there had emerged a new awareness of the ideographic or other potential in alphabetic writing among the experimental writers and no less among the engineers and scientists who designed the prosthetic machines. Kittler has shown in Discourse Networks that the autoexperiment on letter combinations conducted by Hermann Ebbinghaus in psychophysics in the late nineteenth century, which involved randomness and combinatorics, was a direct precursor to this modernist shift toward technologized inscription. "Of course, Ebbinghaus worked with phonemes in order to be able to read aloud," Kittler argues, "but they were presented to him as writing. Syllable after syllable comes out of the random generator,

27. Daniel Tiffany suggests that the radioactive properties of the ideogram appealed to Pound as a means of "radicalizing" the electromagnetic spectrum. See Daniel Tiffany, Radio Corpse: Imagism and the Cryptaesthetic of Ezra Pound (Cambridge, Mass., 1995), p. 225. See also Laszlo Géfin, Ideogram: History of a Poetic Method (Austin, Tex., 1982).

28. Pound, "Pragmatic Aesthetics of E. P. (c.1940-1943)," "Machine Art" and Other Writings: The Lost Thought in the Italian Years, ed. Maria Luisa Ardizzone (Durham, N.C., 1996), p. 158.

29. For a helpful clarification of Wittgenstein's semiotic approach to mental imagery and hieroglyphics, see Mitchell, Iconology, pp. 14-27.

30. Pound, "Vorticism," Fortnightly Review 96, n.s. (Sept. 1914): 464, 466, 463, and 466. 
onto the desk and into the file of worked-through alternatives, until all 2,299 have been used and output and input can begin again." The human mind that undergoes this test cannot but abandon the position of a knowing subject. What it means is that "the two mechanical memories on either side of the tabula rasa Ebbinghaus - the one generating the syllables and the other recording them after they have passed before him —-form a writing machine that forgets nothing and stores more nonsense than people ever could: 2,299 nonsense syllables." 31 This sort of modernist experiment swung violently against a degenerative view of writing expressed by Hegel and critiqued by Derrida in solidarity with Mallarmé, Joyce, and other modernists. The longawaited arrival of the computing machine and information technology upon the scene of writing would soon bring about a number of major developments that reverberated beyond the modernist experiments with ideography, typography, and nonsense letter-combinations to fashion a novel conception of Printed English or the universal English alphabet.

\section{The Importance of Printed English}

Shannon, who invented information theory, approached English not as a printed language but as a statistical system, which he calls Printed English. ${ }^{32}$ This cybernetic concept ought to be rigorously distinguished from the written English word reproduced with the help of the printing press or other means of mechanical reproduction. In other words, Printed English has less to do with mechanical reproduction or the visible print we normally associate with bookmaking than it does with mathematics or statistical science. ${ }^{33}$ As a postphonetic system, Printed English or statistical English func-

31. Kittler, Discourse Networks 1800/19oo, trans. Michael Metteer and Chris Cullens (Stanford, Calif., 1990), p. 211.

32. Shannon conceived of Printed English as an object of mathematical analysis. The rigor of his discipline required him to elaborate the idea in mathematical theorems, tables of digrams, trigrams, probabilities, and so on rather than in purely verbal descriptions. "Printed English" first appeared in the title of his seminal essay "Prediction and Entropy of Printed English." It was also discussed in explicit verbal terms in some of his published papers: see Claude Shannon, "Prediction and Entropy of Printed English," "Communication Theory-Exposition of Fundamentals," (p. 175) and "Information Theory" (p. 215), Collected Papers, ed. N. J. A. Sloane and Aaron C. Wyner (New York, 1993), pp. 294-208, 175, 215. Occasionally, Shannon would use "Printed English" interchangeably with "statistical English." See Shannon, "Communication Theory-Exposition of Fundamentals," p. 174 and "Samples of Statistical English," unpublished paper, 11 June 1948, Shannon papers, the AT\&T Bell Laboratories library, Murray Hill, N.J.

33. Mitchell's critique of Walter Benjamin's notion of "mechanical reproduction" should help us grasp the specific challenges posed by biocybernetics. In "The Work of Art in the Age of Biocybernetic Reproduction," Mitchell defines biocybernetic reproduction as a "combination of computer technology and biological science that makes cloning and genetic engineering possible" and, in a more extended sense, biocybernetic reproduction is "the new technical media and structures of political economy that are transforming the conditions of all living organisms on this planet" (Mitchell, "The Work of Art in the Age of Biocybernetic Reproduction," Modernism/ Modernity 10 [Sept. 2003]: 483). 
tions as a conceptual interface between natural language and machine language. This peculiar English is composed of a 27-letter alphabet from A to $\mathrm{Z}$ plus a space sign. The typewriter can work as an analogue to this cybernetic concept, but even the typewriter turns out to be more than an analogue because it is conceptually related to the birth of Printed English. To be sure, the printing press and the typewriter both entail the mechanical reproduction of graphic symbols on typographical surfaces, but the idea of typesetting, which has been germane to the printing press and remained the same for centuries, is irrelevant to the operation of a typewriter. Central to the typewriter is a single moving typing-head that can print in one-dimensional space (horizontal line) and is constrained to move only to the right or to the left. Owing to the originality of its typinghead, to which were then added the functions of reading and erasing when the computer came along, this prosthetic device has done more for writing and alphabetic writing than perhaps any other device in world civilization since Bi Sheng's invention of movable type in the middle of the eleventh century. ${ }^{34}$ As far as the entanglement of literature and science is concerned, the typing-head has opened up more innovative spaces than we may infer from the well-documented lore of modern novelists and poets who dictate to typists or use the machine themselves. ${ }^{35}$

My point here is not to reiterate Kittler's insights about the role of the typewriter in modern social life but to draw attention to an aspect of biocybernetics that has heretofore escaped the notice of many who investigate hypertext events and biocybernetic literature, namely, Printed English. Modest as it may appear at first, Printed English is one of the most signifi-

34. The conspiracy of silence on the issue of who invented movable type is nothing short of astounding when we consider that the invention of movable type in China is well documented and readily available in English. Movable type was invented in 1041-1048 by Bi Sheng (or Pi Sheng, c.990-1051), who adopted movable types made of earthenware. Documented wooden movable types appeared in 1297-1298, and bronze and metal movable types became widespread in China and Korea in the fifteenth century. For a detailed study of the growth and refinements of early woodcut printing to the spread of printing from movable type as well as Gutenberg's exposure to this technology before 1456, see Tsien Tsuen-Hsuin, Paper and Printing, vol. 5, pt. 1 of Science and Civilisation in China, ed. Joseph Needham (Cambridge, 1985), pp. 201-22, 313-19.

35. McLuhan mentions how the typewriter had become a confirmed habit with Henry James by 1907. "He became so attached to the sound of his typewriter that, on his deathbed, Henry James called for his Remington to be worked near his bedside" (Marshall McLuhan, Understanding Media: The Extensions of Man [1964; Cambridge, Mass., 1994], p. 260). In the case of Hart Crane, Brian Reed shows how central the prosthetic machines had become to the poet: "Hart Crane had an infuriating way of writing a poem. Typically, after drinking copiously, he would put a 78 on a hand-cranked Victrola and play it 'a dozen, two dozen, three dozen times' while alternately banging away on a typewriter and loudly declaiming the same line of verse repeatedly" (Brian Reed, "Hart Crane's Victrola," Modernism/Modernity 7 [Jan. 2000]: 99). For a superb literary analysis of the typewriter and its social history, see Kittler, Gramophone, Film, Typewriter, trans. Geoffrey Winthrop-Young and Michael Wutz (Stanford, Calif., 1999), pp. 183-263. 
cant biocybernetic inventions since World War II. The official date of its initial appearance may be traced to 1948 when Claude Shannon brought out his pathbreaking essay entitled "A Mathematical Theory of Communication" in Bell System Technical Journal. This important essay laid the statistical foundation for communication engineering and became the fountainhead of information theory. Two years later, Shannon followed up with "Prediction and Entropy of Printed English," which elaborates the experimental work in connection with the 1948 essay. These studies show many connections with his earlier work during World War II when he had investigated the statistical aspects of alphabetic writing in cryptanalysis and helped design secrecy systems at Bell Laboratories for the U.S. military. For instance, Shannon was the author of a confidential report entitled "A Mathematical Theory of Cryptography," known as Memorandum MM 45110-02, September 1945, at Bell Laboratories. After declassification in 1949, the report was published as "Communication Theory of Secrecy Systems" in Bell System Technical Journal. ${ }^{36}$

Shannon understood Printed English as an ideographical alphabet with a definable statistical structure. This postphonetic construct entails a symbolic correspondence between the twenty-seven letters and their numeral counterparts in lieu of mapping the letters onto the phonemic units in the spoken language. The alphanumerical correspondence not only facilitates the encoding of messages in information systems but also enables a rethinking of the idea of communication. In everyday usage, information is usually regarded as having some sort of bearing on the semantics of a message. But the linguistic definition of meaning or even message is irrelevant to communication theory. For Shannon, information exists insofar as there is a choice of alternative messages or alternative sequences of letters. If there existed only one possible message (a letter sequence or character string), there would be no information and no need for a transmission system because that message would be on record at the receiving point. From the viewpoint of mathematics, information is related primarily to the factor of uncertainty or probability. If a given message is overwhelmingly probable, the amount of information or the a priori uncertainty will be small. The letter $e$ in English, for instance, occurs more frequently than $q$, and the sequence th more frequently than $x p$, and so on..$^{37}$ The 10o-letter sequence in the opening page of Finnegans Wake can be statistically demonstrated to be overwhelmingly improbable in English and, therefore, the amount of in-

36. See Shannon, "Communication Theory of Secrecy Systems," Bell System Technical Journal 28 (Oct. 1949): 656-715.

37. See Shannon and Warren Weaver, The Mathematical Theory of Communication (Urbana, Ill., 1963), p. 39; hereafter abbreviated MTC. 
formation or uncertainty it carries is very great, even though this information has nothing to do the semantics of the message. For Joyce, the 100-letter sequence-bababadalgharaghtakamminarronnkonnbronntonnerronntuonnthunntrovarrhounawnskawntoohoohoordenenthurnuk visually evokes the fall it describes, whereas for Shannon it would probably spell out the statistical structure of the information where no "space" occurs inside the unusual character string between the first $b$ and the last $k$. In neither case, however, does the information of this letter sequence correspond to a meaningful linguistic unit known as the word. Joyce's intuition about the letter sequence as a nonword is borne out by Shannon's assumption that anyone who speaks a language possesses implicitly an enormous knowledge of the statistical structure of that language. ${ }^{38}$ This may be demonstrated by the higher frequencies of "bab," "bad," kon," or "thu" versus the lower frequencies of "rrh," "nnt," and so on within the Joycean sequence.

From the mathematician's point of view, our implicit knowledge of the statistical structure of language can be converted to a set of numerical data with the help of simple experiments. The experiments are carried out to determine a stochastic process known in mathematics as the discrete Markoff process. The Markoff process describes a finite number of possible "states" of a system: $S_{1}, S_{2}, \ldots, S_{n}$. In addition, there is a set of transition probabilities, $p i(j)$, the probability that if the system is in state $S i$ it will next go to state $S j$. In the case of the finite alphabet of twenty-seven letter symbols in Printed English, state $S j$ might be represented by one of the twentysix letters or the space symbol. Thus the distribution of future states depends on the present state and not on how it arrives in the present state. On the basis of the present state, one can predict, for example, that the probability of the letter $q$ being followed by the letter $u$ is very high in English. "To make the Markoff process into an information source," Shannon suggests that "we need only assume that a letter is produced for each transition from one state to another. The states will correspond to the 'residue of influence' from proceeding letters" (MTC, p. 15). This process provides the stochastic structure for an experiment in which a human subject is asked to guess an unknown text in the language letter by letter. At each letter the subject guesses what he or she considers the most probable next letter in view of the preceding text. In cases where an error is made, he or she is required to guess again and again until he or she arrives at the correct next letter. This represents a huge mathematical leap over the similar kinds of experiments from the past, like the Ebbinghaus autoexperiment in psycho-

38. See Shannon, “Communication Theory-Exposition of Fundamentals," p. 175. 
physics or the pseudo-experiments that I. A. Richards conducted on his students using printed sheets of poems. ${ }^{39}$

How does one define a quantity that will measure how much information is produced by such a process? How much information in bits (binary digits) per second is produced in a given source? Using Boltzmann's $H$ theorem, Shannon defines that quantity as $\mathrm{H}=-\Sigma p_{\mathrm{i}} \log p_{\mathrm{i}}$ and calls the $H$ the "entropy" of the set of probabilities where $p i$ is the probability of a given symbol $i$ (MTC, p. 20). Like entropy in thermodynamics, from where the idea originally derives, information entropy measures how much randomness there is in a letter sequence or in a signal. This quantity makes it possible for an engineer to estimate the average minimum number of bits needed to encode a string of symbols based on the frequency of the symbols. ${ }^{40}$ For the engineer, "the main point at issue is the effect of statistical knowledge about the source in reducing the required capacity of the channel, by the use of proper encoding of the information" (MTC, p. 10). But the thing that concerns us here is not the engineering aspect of the information system but what this work has done to the idea of the phonetic alphabet.

I mentioned in passing that Shannon had conducted a series of experiments to ascertain the stochastic properties of English. Although it is not clear whether passages from Finnegans Wake were actually assigned to one of the human subjects taking the tests, Joyce's book is singled out as a typical case of low redundancy within the range of stochastic possibilities allowed by English prose..$^{41}$ In A Mathematical Theory of Communication, Shannon describes "two extremes of redundancy in English" that are each "represented by Basic English and by James Joyce's book Finnegans Wake." The Basic English vocabulary, he says, "is limited to 850 words and the redundancy is very high. This is reflected in the expansion that occurs when a

39. Richards documents and analyzes the results of his experiments in his influential book Practical Criticism (New York, 1929), esp. pts. 1 and 2.

40. Shannon uses a simple example to demonstrate how one could estimate the average minimum number of bits needed to encode a string of symbols based on the frequency of the symbols. He considers a sequence of letters A, B, C, D and assigns the probabilities $1 / 2,1 / 4,1 / 8,1 / 8$ to them with successive symbols being chosen independently. This is expressed in the following equation as

$\mathrm{H}=-\left(1 / 2 \log ^{1} / 2+1 / 4 \log _{1} 1 / 4+3 / 8 \log ^{1 / 8}\right)$

$$
=7 / 4 \text { bits per symbol }
$$

The result enables the approximation of a coding system to encode messages from this source into binary digits with an average of $7 / 4$ binary digit per symbol. See MTC, p. 32. For further application of the Shannon entropy equation to computer engineering, see David Salomon, $A$ Guide to Data Compression Methods (New York, 2002).

41. In a conversation at the Wissenschaftskolleg zu Berlin in April 2005, Kittler mentioned an interesting detail to me in connection with Shannon's reading of Joyce. He suggested that Shannon was introduced to Joyce's work by his wife Mary Elizabeth (Betty) Shannon. 
passage is translated into Basic English. Joyce on the other hand enlarges the vocabulary and is alleged to achieve a compression of semantic content" (MTC, p. 26).42 Shannon is naturally unconcerned with what he calls the semantic content of English since he is mainly interested in the stochastic structure of the language. With the good insight of a mathematician, he immediately grasps the fact that the redundancy of a language is somehow related to the rationale of word puzzles. If the redundancy is zero, he shows that any sequence of letters is a reasonable text in the language, and any two-dimensional array of letters can form a crossword puzzle. In one experiment, he calculates the redundancy of English at roughly 50 percent, which makes large crossword puzzles possible. However, when the redundancy is lowered to 33 percent, three-dimensional crossword puzzles become a possibility. I suppose that Joyce scholars might gain additional insight into his feat of engineering by analyzing the stochastic dimension of his multilingual riddles in Finnegans Wake. I am aware that this idea may strike some literary critics as frivolous, but it is not. In 1922, as Joyce began working on Finnegans Wake, Harry and Caresse Crosby proposed that someone should write an introduction to his Tales Told of Shem and Shaun, which were fragments from Work in Progress. Joyce suggested Julian Huxley and J. W. N. Sullivan, but

when the scientist and the musicologist made excuses, he then proposed C. K. Ogden, rightly surmising that the co-author of The Meaning of Meaning and the inventor of Basic English would not resist an invitation to discuss this linguistic experiment. He wished also for Ogden to comment, as a mathematician, upon the structure of Finnegans Wake, which he insisted was mathematical. If Ogden had refused, Ford Madox Ford was to have been asked, but Ogden accepted, and later was to translate Anna Livia Plurabelle into Basic, and to arrange for Joyce to record that fragment for the Orthological Institute. ${ }^{43}$

Ogden was a great admirer of Joyce's work and later contributed a preface to the Black Sun edition of Tales Told of Shem and Shaun in 1929.

In Basic English: International Second Language, Ogden hypothesizes that "the 'normal vocabulary of the average man' hovers between the alleged 300 words of the Somersetshire farmer, the 4,000 of President Wilson's State

42. The expansion of which he speaks was actually carried out by the author of Basic English, C. K. Ogden himself. In Basic English: International Second Language, Ogden includes a series of translations in the appendices from the original English texts, literary as well as scientific, into his 850-word Basic English. Some of the translations come from the Bible and popular literary texts such as Alcott's Little Women, Shaw's Arms and the Man, and Stevenson's Treasure Island. See C. K. Ogden, Basic English: International Second Language (1930; New York, 1968); hereafter abbreviated BE.

43. Richard Ellmann, James Joyce (1959; New York, 1982), p. 614. 
Papers, the 7,000 of the Japanese diplomat, the 12,000 of the Eskimo fisherman or the average undergraduate, the 30,000 of Sir Vade Mecum, C.V.O. at Geneva, and the 250,000 of a James Joyce" (BE, p. 9). The author's grasp of the statistical implications of Joyce's literary experiment is almost prescient as it anticipates the way in which Shannon would make use of Finnegans Wake and Basic English decades later. Ogden does not explain how he came up with this last estimate or whether the colossal number represents the size of the entire Joycean vocabulary with both words and nonwords included. The statistical dimension of Ogden's 850-word vocabulary was the linguist's foremost concern from the start, which no doubt justifies Shannon's treatment of Basic and Finnegans Wake as the extreme opposites of redundancy and entropy. In this sense, information theory is simply the logical outcome of the earlier crossbreeding of ideas in the literary and scientific experiments carried out systematically by Joyce, Ogden, and other writers and scientists.

Yet not even in his most iconoclastic moments would Joyce abandon meaning in his forays into the exotic letter sequences. As a matter of fact, he endeavored to produce polyseme and create the illusion of polyphony whenever possible. With Shannon, it is a different matter. The mathematician has taken the experiments with Printed English further into the realm of pure ideographic symbols. In so doing, he introduces a radical rupture between the phonetic alphabet and the spoken language it is supposed to represent. The letter sequences in Printed English are almost entirely devoid of linguistic meaning and sound inasmuch as what is left of meaning is made to migrate from language to the ideographic utopia of mathematical symbols. This rupture is more radical than the conventional division of labor between the mathematical uses of alphabetical symbols such as algebra and the natural languages used in written communication because the very notion of communication in alphabetical writing is being challenged and refigured. N. Katherine Hayles has treated Shannon's bracketing of semantics as a strategic choice because "he did not want to get involved in having to consider the receiver's mindset as part of the communication system." ${ }^{44}$ This observation makes good sense in light of her consideration of the alternative theory of information proposed by Donald MacKay, which did require the measurement of psychological states..$^{45}$ But the issue that concerns us here is less about the decision to include or exclude semantics than

44. N. Katherine Hayles, How We Became Posthuman: Virtual Bodies in Cybernetics, Literature, and Informatics (Chicago, 1999), p. 54.

45. For a recent critique of Hayles's interpretation of Shannon versus MacKay, see Mark B. N. Hansen, "Cinema beyond Cybernetics, or How to Frame the Digital Image," Configurations 10, no. 1 (2002): 51-90. 
it is about the making of a theoretical construct called Printed English that makes a unique demand on meaning or the expulsion of linguistic meaning. This construct is what has been overlooked by contemporary scholarship on informatics.

Take the peculiar twenty-seventh letter. This is a sign for space, which belongs to one of the "states" of the alphanumerical system: $S_{1}, S_{2}, \ldots, S_{\mathrm{n}}$ in the Markoff chain. By virtue of being a nonphonetically marked symbol, the twenty-seventh letter activates the statistical structure of the twenty-sixletter alphabet; yet it can hardly function in this capacity until the remaining twenty-six letters in the system are made to function simultaneously as equivalent, ideographical signs. I use the verb activate to highlight an aspect of the phone alphabet that is prone to statistical treatment by virtue of its evolution from ancient alphanumerical systems, for numerical signs were closely linked to the origin of writing. Take the word spr for scribe in Phoenician. This word originally derived from the verb to count and only later began to acquire the meaning "to write." ${ }^{6}$ Shannon's space symbol renders the statistical structure of the alphanumerical system visible in the spirit of the ancient alphanumerical spr. This is accomplished through the use of what he calls the mathematical approximation of letter sequences. When visualized, his letter sequences may appear as nonwords or ungrammatical units whereas the stochastic structure in them has nothing to do with either visualization or phoneticization. A zero-order approximation to English prose, which would give random combinations of independent and equiprobable symbols, might generate the following: "XFOML RXKHRJFFJUJ ZLPWCFWKCYJ FFJEYVKCQSGHYD QPAAMKBZAACIBZLHJQD.” Moving to the next order, and the next, and so on through the second-order word approximation, we may get a sequence of recognizable word units in which the word transition probabilities are incorporated where no further structure is included. Thus a less random sequence is produced, which may look like this: "THE HEAD AND IN FRONTAL ATTACK ON AN ENGLISH WRITER THAT THE CHARACTER OF THIS POINT IS THERE-

46. See Corinne Bonnet, "Les Scribes phénico-puniques," in Phoinikeia Grammata: Lire et écrire en Méditerranée, ed. Claude Baurain, Bonnet, and V. Krings (Namur, 1991), p. 150. In a recent article Dimitris K. Psychoyos points out that in ancient Greek and other ancient writing systems the use of letters of the alphabet was clearly constrained by the necessities of mathematics since the twenty-four letters of the alphabet plus the additional three signs were used to notate numbers. He argues that from the very beginning the twenty-seven letters had been there to meet the needs of mathematics, namely, the necessity of using the enneads of the Egyptian numerical system. The phonetic alphabet must, therefore, be understood "in the context of a wider semiotics of writing" and as part of a "wider process of production of the written signs, which 'represent' not things (as painted images did) but meanings" or "human Reason in general and not specifically human speech" (Dimitris K. Psychoyos, "The Forgotten Art of Isopsephy and the Magic Number KZ," Semiotica 154 [Apr. 2005]: 209). 
FORE ANOTHER METHOD FOR THE LETTERS THAT THE TIME OF WHO EVER TOLD THE PROBLEM FOR AN UNEXPECTED" (MTC, pp. $13,14)$. Shannon's reader may be greatly tempted to scrutinize the semantic dimension of these letter sequences the same way Joyce's reader endeavors to make sense of Finnegans Wake. Why frontal attack on an English writer? Which writer? But semantic treasure hunts with Shannon would lead us nowhere except for a bit of local irony. For what he is doing here is demonstrating that a sufficiently complex stochastic process can give us a satisfactory representation of a discrete source out of which a particular sequence of ten words- "ATTACK ON AN ENGLISH WRITER THAT THE CHARACTER OF THIS”-is not entirely unreasonable even by the criterion of semantics, although information theory does not operate according to this criterion. The sequences we have just seen are more dependent on the stochastic frequency of the sign space than they are on the units of letters, whether they be words or nonwords. To my knowledge, the only linguist from the Prague Linguistic Circle who has noted this phenomenon, and then only in passing, is Josef Vachek. ${ }^{47}$ In an essay called "Remarks on Redundancy in Written Language with Special Regard to Capitalization of Graphemes," Vachek brings up the term "graphemic zero" and defines it as the "empty spaces between written (or printed) words in the graphical context." 48 This visual marking of space seems to lack the rigor of Shannon's twenty-seventh letter or what Derrida has done with spacing. But to his credit, Vachek stands out as the lone functionalist who has persisted in the study of writing and even devoted an essay to the subject of "Written Language and Printed Language" in a time when the majority of his fellow linguists were still preoccupied with the phoneme.

The centrality of the printed word and the printed nonword for technology has something to do with the fact that, to use Kittler's words, "in contrast to the flow of handwriting, we now have discrete elements separated by spaces." ${ }^{49}$ It should be emphasized, however, that the space symbol is a conceptual figure in Printed English, not a visible word divider as is

47. Vachek is a leading functionalist and has authored numerous articles on the subject of "written language," which, unfortunately, have not drawn as much attention as some of the other members of the Prague school due to the phonocentric biases of modern linguistics.

48. Josef Vachek, "Remarks on Redundancy in Written Language with Special Regard to Capitalization of Graphemes," Written Language Revisited, ed. Philip A. Luelsdorff (Amsterdam, 1989), p. 152. The concept of "graphemic zero" allows Vachek to posit the essential differences between writing and speech. He writes: "one does not find in equivalent spoken contexts any acoustic 'zeros,' i.e. any brief pauses separating spoken words-if such pauses do exist, there must be some specific reason for their occurrence.... Whereas the above-noted graphemic zeros function automatically and quite consistently" (ibid., pp. 152-53). See also Vachek, Written Language: General Problems and Problems of English (The Hague, 1973).

49. Kittler, Gramophone, Film, Typewriter, p. 16. 
commonly observed in modern and some of the ancient writing systems, such as Akkadian cuneiform. This sign may occasionally show up as a negative value or as the visible absence of letters, but the twenty-seventh letter is just as likely to be mathematically represented by o as by one or two types of electric pulse on a transmission pulse system. The letter owes its existence to the statistical, rather than visual or phonemic, parameters of symbols. It has no linguistic meaning insofar as conventional semantics is concerned, but it is fully functional as a meaningful ideographical notion. In fact, the twenty-seven letters of Printed English belong altogether to a different metaphysics than that targeted by Derrida's critique because the binary opposition of speech and writing does not obtain here. What we find instead is a monism of statistical thinking that arbitrates the entropy of discrete alphanumerical symbols in a binary opposition of o and 1. For Shannon, the entropy is a statistical parameter that measures how much information is produced on the average for each letter of a text in a language. With an efficient translation of that language into binary digits (o or 1), the entropy $H$ is the average number of binary digits required per letter of the original language. In "Prediction and Entropy of Printed English," Shannon further suggests that "in ordinary literary English, the long range statistical effects (up to 100 letters) reduce the entropy to something of the order of one bit per letter, with a corresponding redundancy of roughly $75 \% .{ }^{50}$ This, of course, applies to the amount of information transmitted by discrete symbols. Where speech waves or television signals are concerned, we are confronted with continuous cases rather than the input or output of discrete alphanumerical symbols. To convert this type of continuous information to discrete cases, Shannon has generalized the statistical mechanism to include a variable of time that enables the measuring of units of information per second, as opposed to per symbol, in transmitting speech signals, visual signals, or other continuous signals..$^{51}$ By no means does the statistical paradigm presuppose a binary opposition between speech and writing, for all information assumes the form of continuous or discrete input and output.

As a discrete ideographic symbol, the twenty-seventh letter is meaningful in precisely this statistical sense. Shannon's experiment with the stochastic structure of a randomly chosen text, Dumas Malone's Jefferson the Virginian, has produced further results. They suggest that the predictability of English is dependent on the space letter far more frequently than on any of the other letters in the alphabet. Where there are no known letters, for ex-

50. Shannon, "Prediction and Entropy of Printed English," Bell System Technical Journal 30 (Jan. 1951): 50; hereafter abbreviated "PE."

51. See Shannon, "Communication Theory—Exposition of Fundamentals," p. 175, and MTC, pp. 81-96. 
ample, the most probable guess is the space symbol (probability o.182) and if this turns out to be wrong, the next probable guess would be $E$ (probability 0.107), and so on (see "PE," p. 57). Shannon concludes that "a machine or person guessing in the best way would guess letters in the order of decreasing conditional probability. Thus the process of reducing a text with such an ideal predictor consists of a mapping of the letters into the numbers from 1 to 27 in such a way that the most probable next letter [conditional on the known preceding $(N-1)$ gram] is mapped into 1, etc." ("PE," p. 58). As if it mirrored cryptography, Printed English always has a corresponding translated text in numerical symbols. The original text "with an alphabet of 27 symbols, $A, B, \ldots, Z$, space, has been translated into a new language with the alphabet 1, 2, , 27" (“PE," p. 56). This conception laid the foundation for what would become the ASCII code (American Standard Code for Information Interchange) and other codes in computer science. Through a built-in mechanism of alphanumerical translation, Printed English achieves its ultimate ideographic embodiment in the mathematical figuring of $0 / 1$ binary oppositions. ${ }^{52}$

So when Shannon claims that " $H$ measures the equivalent number of binary digits for each letter produced in the language in question. $\mathrm{H} \mathrm{mea-}$ sures all languages by the common yardstick of binary digits," he is reducing every known language to a variant of Printed English including the ordinary English language itself. ${ }^{53}$ In fact, Warren Weaver-the powerful gatekeeper of the postwar scientific establishment in the U.S. who published the singlevolume edition of Shannon's Mathematical Theory of Communication —had circulated a memorandum as early as July 1947 among two hundred leading mathematicians, scientists, linguists, and public policy makers in which he outlined the future prospect of a universal English code. He wrote: "It is very tempting to say that a book written in Chinese is simply a book written in English which was coded into the 'Chinese code.' If we have useful methods for solving almost any cryptographic problem, may it not be that with proper interpretation we already have useful methods for translation?" ${ }^{54}$

52. The role of translation in biocybernetics is an important one and is discussed in my forthcoming essay "How the English Alphabet Became Ideographic?" in Divided Loyalties, ed. Louis Menand (London, 2006).

53. Shannon, "Communication Theory-Exposition of Fundamentals," p. 174; my emphasis.

54. Quoted in Rita Raley, "Machine Translation and Global English," Yale Journal of Criticism 16 (Fall 2003): 296. The rise of Printed English as a universal code has major implications for machine translation projects. According to Raley, the company Systran, which has pioneered a software program called SYSTRAN Professional Premium 5.o., currently operates AltaVista's web translation system Babelfish and provides machine translation service for the European Union and the U.S. intelligence community. What is so interesting about their translation program is that it treats English as a "relay language" whereby a translation from, say, German to Italian must first pass through English; see ibid., p. 311. 
Shannon's Printed English was precisely the kind of response that Weaver was calling for. Coming in the wake of Basic English, Printed English was destined to fulfill the international mission charted out by Ogden and Richards. In fact, what Richards said about the identity of Basic English in 1935 describes the Shannon-Weaver project equally well: "The only way in which false and misleading approximations to Western units of meaning with Chinese 'equivalents' can be avoided is by giving these meanings through, and together with, an apparatus for comparing complex meanings-through an explicit analytic language." ${ }^{55}$ Such an analytical language, concluded Richards, was Basic English. Since the invention of information theory, the mission has subsequently devolved upon Printed English. With the English code being named the original code, Printed English was poised to become the first universal ideographic system with respect to which all other languages of the world would turn into translations.

\section{Empires of the Mind}

The novelty and rigor of his mathematical models notwithstanding, Shannon was not the first theorist to develop a systematic approach to the English language as a statistical system. When Ogden designed Basic English in 1929, the reduced vocabulary of 850 words was intended to provide a sound statistical basis for a universal and international language. The movement for Basic received enthusiastic endorsements from the official establishment of Britain and the United States. In 1943, Winston Churchill wrote, "I am very much interested in the question of Basic English. The widespread use of this would be a gain to us far more durable and fruitful than the annexation of great provinces. It would also fit in with my ideas of closer union with the United States by making it even more worth while to belong to the English-speaking club." ${ }^{56}$ The British prime minister became a goodwilled ambassador for Basic when he delivered a speech at Harvard University in the same year. He urged Americans to understand that "the empires of the future are the empires of the mind." ${ }^{57}$ In the midst of running a war with fascist Germany, Churchill exhibited a shrewd understanding of the value of language for empire building, and he was not disappointed.

55. Richards, Basic in Teaching: East and West (London, 1935), p. 47.

56. Winston Churchill, letter to Edward Bridges, 11 July 1943, in BE, p. 111. Churchill instructed the British cabinet to set up a committee of ministers to study and report on Basic English. The minister of information, the colonial secretary, and the president of the Board of Education were all involved in this effort. When Churchill met Roosevelt at Quebec in 1943, they discussed the possibilities of Basic English. According to a White House memo, Roosevelt was very interested in the idea of making Basic English replace French as a "language of diplomacy" (Franklin Delano Roosevelt, memo to secretary of state, 5 July 1944, in BE, p. 115).

57. Churchill, speech given at Harvard University, 6 Sept. 1943, in BE, p. 113. 
Among the enthusiastic academic champions of Basic was Richards, whose name Churchill mentioned in his speech. Not only did Richards coauthor The Meaning of Meaning with Ogden four years before the invention of Basic, but he took the cause of Basic to Beijing, one of the remote frontiers of empire. While teaching at Tsinghua University, Richards spent several years trying to persuade the Ministry of Education in the Republic of China to adopt Basic to help modernize the country's educational system. Working with his friends and educators in Beijing, he came close to implementing a course of Basic English in the nation until the war with Japan broke out and interrupted the effort. ${ }^{58}$

The imperial agenda of Basic is visibly written upon the face of the acronym BASIC: British, American, Scientific, International, and Commercial. This artificial language succeeded in attracting the attention of many politicians, educators, and writers of the time for different reasons. Pound, for example, wrote a review of Ogden's book Debabelization in 1935, commenting that "if a novelist can survive translation into basic, there is something solid under his language." As a means of transmission, Basic was deemed obviously "superior to the 'Times' fog or 'Manchester Guardian' twitter." ${ }^{59}$ To its architect Ogden, however, the hegemony of imperial English and the practicality of simplified language learning for international commerce and politics and its stylistic challenges are some of the reasons but not the only ones for promoting Basic. He viewed scientific stability and advances in a number of statistical domains as the immediate theoretical impetus for the project: "the system of numbers, the metric system, the measurement of latitude and longitude, mathematical symbols, chemical formulae, time and the calendar," and "notation in music." "The two main reasons for making English the basis of a universal language," Ogden argues, "are (1) the statistical considerations set forth above, and (2) the fact that English is the only major language in which the analytical tendency has gone far enough for purposes of simplification" (BE, pp. 14-15). This view was a novel idea when Ogden first constructed Basic to reduce the English vocabulary to 850 words. What is new here is not his imagining of a universal language, which may be traced as far back to the seventeenth century if not earlier, but rather a conception of English as a statistical system. By no accident did Ogden become the English translator of Ludwig Wittgenstein's Tractatus Logico-Philosophicus, in which the philosopher demonstrates a

58. For a detailed study of Richards's extensive involvement in the Basic English project at the Ministry of Education in China, see Q. S. Tong, "The Bathos of a Universalism: I. A. Richards and His Basic English," in Tokens of Exchange: The Problem of Translation in Global Circulation, ed. Liu (Durham, N.C., 1999), pp. 331-54.

59. Pound, "Debabelization and Ogden," New English Weekly, 28 Feb. 1935, p. 411. 
logical system of numbered propositions to illustrate their nested interrelations. ${ }^{00}$

We have seen how Shannon, who was deeply involved in World War II on the American side as a cryptographer, took this logical and statistical notion of language a step further to launch a new discipline. Norbert Wiener recalls in Cybernetics that Shannon, R. A. Fisher, and he himself began at around the same time to approach the message as "a discrete or continuous sequence of measurable events distributed in time-precisely what is called a time series by the statisticians" and that "the unit amount of information was that transmitted as a single decision between equally probable alternatives." ${ }^{11}$ In addition, he draws attention to the fact that the statistical definition of message was relatively a latecomer in communication engineering when scientists had been using statistical mechanics in nearly every branch of science for more than a century.

Of course, that is not the whole story. Basic English assumes the primacy of the printed word in the requirement that the special arrangement of the 850 words be visual, legible, and easily portable. In the opening paragraph of Basic English, Ogden asserts that

it is clear that the problem of a universal language would have been solved if it were possible to say all that we normally desire to say with no more words than can be made easily legible to the naked eye, in column form, on the back of a sheet of notepaper. The fact, therefore, that it is possible to say almost everything we normally desire to say with the 850 words on the endpapers, which occupy about three-quarters of the space on the back of an ordinary sheet of business notepaper, makes Basic English something more than a mere educational experiment. [BE, p. 5; my emphasis]

How does the act of saying things implicate a sheet of notepaper or the naked eye except that the verbal saying is a metaphor for reading? The mention of the column form and business notepaper no doubt implies the overall practical purposes that Basic English is supposed to serve, but they also raise some theoretical questions about the status of the printed word. Here

60. See Ludwig Wittgenstein, Tractatus Logico-Philosophicus, trans. Ogden (London, 1981), p. 8. Ogden showed more appreciation of the significance of Wittgenstein's work than the other publishers and editors Wittgenstein had approached in Germany or England. After rejection by the Cambridge University Press, Tractatus Logico-Philosophicus found a sympathetic ear in Ogden, who, as the general editor of a well-known scholarly series entitled the International Library of Psychology, Philosophy, and Scientific Method, translated and published the book with Kegan Paul. 61. Wiener, Cybernetics, or Control and Communication in the Animal and the Machine, pp. 8-9, 10. 
Ogden does not specify whether he has in mind the written or printed word. It seems to me that the latter, at least in a conventional sense, is strongly implied; elsewhere, the author quotes approvingly the report printed in the Daily Mail: "The whole vocabulary of this Basic English can be printed comfortably on a sheet of notepaper." 62 If this seems to allude to commonplace typescripts and printed inserts to be found in nearly all his Basic books Ogden is aiming toward a far more ambitious and universal technology of telecommunication. In Debabelization, he states:

So far we have considered the question of Debabelization only as it presents itself to the publicist, the linguist, and the statistician. But the past ten years have introduced a new voice into all discussions of the international future. It is the business of the Inter-linguist to bring it home to the world that the electrical engineer has to-day brought the World into the home. International Radio, international Talkies, international Telephone- these are to be the decisive factors in this coming century. ${ }^{63}$

Despite his visionary predilections, Ogden did not foresee the arrival of an electronic engineer like Shannon who would take an interest in Basic or a mathematician like Alan Turing whose work would fundamentally alter the meaning of language, writing, communication, and even the thought process itself.

When Turing first imagined the computing machine in 1936, he was thinking in terms of a supertypewriter that would be able to read, erase, or print symbols on a strip of paper that was to be marked off into cells or squares. In fact, he had come upon the idea by closely examining typewritten letters and symbols. He analyzed in particular how the space bar and backspace determined the printing position and how the typing point, which could be moved relative to the page, was independent of the typing action. There were obvious limitations in a typewriter because the typing point, moving to the left or right, could only print one line of symbols at a time and could not read or erase symbols, and "it required a human operator to choose the symbols and changes of configuration and position." ${ }^{64}$ With the universal discrete machine, the act of scanning or marking the paper tape would displace the acts of reading and writing and render the linguistic categories of phonemes, semes, and words superfluous for the

62. Ogden, Debabelization: With a Survey of Contemporary Opinion on the Problem of a Universal Language (London, 1931), p. 76.

63. Ibid., p. 71 .

64. Andrew Hodges, Alan Turing: The Enigma (New York, 1983), p. 97. 
purpose of communication. ${ }^{65}$ Turing developed his new ideas in the groundbreaking essay "On Computable Numbers" in which he proposes that his machine be supplied

with a "tape" (the analogue of paper) running through it, and divided into sections (called "squares") each capable of bearing a "symbol." At any moment there is just one square, say the $r$-th, bearing the symbol $\mathrm{S}(\mathrm{r})$ which is "in the machine." We may call this square the "scanned square." The symbol on the scanned square may be called the "scanned symbol." The "scanned symbol" is the only one of which the machine is, so to speak, "directly aware." However, by altering its m-configuration the machine can effectively remember some of the symbols it has "seen" (scanned) previously. ${ }^{66}$

The centrality of printed symbols in Turing's work allows the machine to take over the human acts of writing, reading, seeing, memorizing, and erasing and organize them into a three-fold mechanical act of scanning, printing, and erasing. The printed symbols presuppose a universal, ideographical script similar to the universal (Hindu-Arabic) numerals to which they also correspond; and these "scanned" letters and space symbols make sense (ideo + graph) to the machine without any involvement of phonic systems whatsoever. Turing's technical refiguring of the act of reading sheds unexpected light on an earlier evocation of "scanning" by Mallarmé in 1897. In his preface to "A Throw of the Dice," the poet had insisted on the significance of "blanks" in his verse, using the word scanning to characterize the movement of printed words as a visual experience, and by extension the reader's eyes following the movement, across typographical spaces. With uncanny foresight into the cybernetic future of typographical spacing, Mallarmé appears to have anticipated Turing's conceptual reading-head of the computer. ${ }^{67}$

What it means is that Ogden's visual conception of columns of words on business notepaper in printed form would soon be technologically superseded by the marking, scanning, and erasing of discrete symbols on the

65. As I mentioned in the preceding section, words and nonwords enjoy the same status in information theory because the communication engineer is not so much concerned with the semantics as with the transmission of letter sequences.

66. Alan Turing, "On Computable Numbers, with an Application to the Entscheidungsproblem," Proceedings of the London Mathematical Society 42, 2d ser. (1937): 231.

67. The original quotation from Mallarmé reads: "L'avantage, si j’ai droit à le dire, littéraire, de cette distance copiée qui mentalement sépare des groupes de mots ou les mots entre eux, semble d'accélérer tantôt et de ralentir le mouvement, le scandant, l'intimant même selon une vision simultanée de la Page: celle-ci prise pour unité comme l'est autre part le Vers ou ligne parfaite” (Stéphane Mallarmé, “A Throw of the Dice," Collected Poems, trans. Henry Weinfield [Berkeley, 1994], p. 121). 
computer tape. When Shannon interpreted Turing's square as "a particular 'blank' symbol," he began to suggest a meaningful parallel between the twenty-seventh letter and the blank (unmarked) square on the paper or magnetic tape of the universal discrete machine. ${ }^{68}$ By installing a nonphonetically marked discrete space or blank sign at the core of the alphanumerical system, information theory and computer technology enable a fundamental distinction between written and printed symbols, an important distinction that has escaped the notice of the majority of linguists and historians of technology. We hear the story of the universal Turing machine being repeated often enough to recognize a lineage of great minds-Charles Babbage, Turing, Konrad Zuse, Howard H. Aiken, and others-who all contributed to the invention of the computer. But hardly any attention has been directed to the question, What has the new technology done to that most familiar technology of all, the phonetic alphabet?

\section{The Conundrum of the Phonetic Alphabet}

Indeed, one of the most difficult tasks facing us today is how to unthink the most commonplace of our assumptions about the phonetic alphabet as a technology—not writing or écriture as yet—and overcome some of the long-held myths and distortions associated with that invention. McLuhan was among the first to grasp the importance of Joyce's experiment for new media, but he did not use that insight to revise his mistaken views of the phonetic alphabet. Those views, shared by many still, continue to buttress the claims people make about the advances in print technology, telecommunication, and biocybernetic technologies since the introduction of movable type into Europe. Here I am not chiefly concerned with the misplaced arrogance in the well-entrenched view that Johannes Gutenberg invented movable type. Rather I am interested in McLuhan's intellectual claims about the phonetic alphabet as a technology. In Understanding Media, he asserts:

The phonetic alphabet is a unique technology. There have been many kinds of writing, pictographic and syllabic, but there is only one phonetic alphabet in which semantically meaningless letters are used to correspond to semantically meaningless sounds. This stark division and parallelism between a visual and an auditory world was both crude and ruthless, culturally speaking. The phonetically written word sacrifices worlds of meaning and perception that were secured by forms like the hieroglyph and the Chinese ideogram. These culturally richer forms of writing, however, offered men no means of sudden transfer from the

68. Shannon, "A Universal Turing Machine with Two Internal States," Collected Papers, p. 733. 
magically discontinuous and traditional world of the tribal word into the cool and uniform visual medium. Many centuries of ideogrammic use have not threatened the seamless web of family and tribal subtleties of Chinese society. On the other hand, a single generation of alphabetic literacy suffices in Africa today, as in Gaul two thousand years ago, to release the individual initially, at least, from the tribal web. ${ }^{69}$

This argument sounds persuasive at the commonsense level but is deeply flawed at the conceptual level, not the least because it is compromised by the ethnocentric claims of civilization versus the tribal other. McLuhan imputes primitive pictographic thinking to nonalphabetical writing despite the fact that this view had been discredited before his time. ${ }^{70}$ Rudimentary knowledge of semiotics or mathematical symbols would have taught us that nonphonetic, visual signs need not be "pictograms" or "tribal" to function as semiotic media. Where the primitivizing of nonalphabetical writing has succeeded so well is the supplementary mystification of the phonetic alphabet itself, which has been the object of my inquiry. For the question then becomes, By what magic does the "cool and uniform visual medium" of "meaningless" phonetic symbols come to bear meaning at all? Unable to confront either the science or the magic of the phonetic alphabet, one is forced to evoke the familiar position of modern linguistic theory and insist that the phonetic letters represent "meaningless" sounds in speech. ${ }^{71}$

Saussure, among others, did try to tackle the issue by attaching the notion of concept to the signifié (signified) in the linguistic sign—which, ironically, cannot but be embodied by the written letter as Derrida has correctly

69. McLuhan, Understanding Media, pp. 83-84.

70. See Peter Boodberg, “'Ideography' or Iconolotry?” T'oung Pao 35 (1940): 266-88, and Yuen Ren Chao, Mandarin Primer (Cambridge, Mass., 1948).

71. McLuhan's ethnocentrism often blinds him to the incoherence and self-contradiction of his ahistorical views concerning technology and civilization. If the phonetic alphabet has played such a decisive role in liberating individuals from their familial and tribal webs, why did it take thousands of years for the West to discover the value of individualism whereas "a single generation of alphabetic literacy suffices in Africa today"? In an essay called "Cybernetics and Culture," McLuhan, citing Lynn White's Medieval Technology and Social Change, points out that the stirrup, as an extension of the foot, was unknown to the Greeks and Romans. Its first introduction from the East (China) enabled men in the early medieval world "to wear heavy armor on horseback" and become "tanks." The feudal system that came into existence to pay for heavy armor owed itself to the introduction of this technology. But when gunpowder entered the scene, it immediately "changed the ground rules of the feudal system as drastically as the stirrup had changed the ground rules of the ancient economy. It was as democratic as print" (McLuhan, "Cybernation and Culture," in The Social Impact of Cybernetics, ed. Charles R. Dechert [Notre Dame, 1966], p. 104). If all three technologies—-the stirrup, gunpowder, and print—originated in China, why were they capable of transforming the West while leaving the "seamless web of family and tribal subtleties of Chinese society" intact? Ethnocentrism seems to be the only possible explanation for this reasoning. 
pointed out—and ended up in a similar kind of conundrum..$^{72}$ Despite Saussure's speculations about arbitrariness and his rare insight into the "global value" of the signe idéographique I discussed earlier, it remains a mystery in linguistic theory as to how the combination of meaningless letters, which correspond to meaningless sounds, can produce meaningful visual inscription. The truth of the matter is that the commonplace of linguistics which says that the phonetic alphabet "sacrifices worlds of meaning and visual perception" is premised on ethnocentric reasoning or inference by exclusion; that is, all nonalphabetical writing systems-hieroglyphs and Chinese writing alike-are made up of primitive pictograms that convey meaning simply by imitating the icon or the physical form of what they represent. This manner of reasoning, which McLuhan appears to endorse reflexively, borrows from European comparative philology that is itself steeped in Christian missionary ethnographies of primitivism and nonalphabetical writing in the course of imperial conquest and colonial rule. ${ }^{73}$

It is significant in retrospect that as the first grammatologist, I. J. Gelb, set out to revise and correct the popular understanding of the world's writing systems in A Study of Writing, he decided to expunge the concept of ideogram from the theory of writing altogether, substituting logograms (graphic signs for words) instead. ${ }^{74}$ Gelb retained the term pictograph and occasionally used semasiography to designate what he called the "forerunners of writing" but reclassified Chinese and other fully developed nonalphabetical writings as logographic systems. In logography, Gelb argued, "the sign has only as many meanings as there are words which are habitually and conventionally associated with it" (SW, p. 106). ${ }^{75}$ According to this view, each written character in the logographic system was a single conventional symbol representing a word(s) and a sound in the language. ${ }^{76}$ The goal of

72. See Derrida's critique of Saussure, especially the latter's imputation of a "thought-sound" division to the concept of the word ( vox), in Derrida, Of Grammatology, pp. 30-44.

73. For my critique of comparative philology, see the chapter "The Sovereign Subject of Grammar" in Liu, The Clash of Empires: The Invention of China in Modern World Making (Cambridge, Mass., 2004), esp. pp. 181-91.

74. See I. J. Gelb, A Study of Writing (Chicago, 1965), pp. 99-107; hereafter abbreviated SW.

75. This can sometimes involve a circular argument that hinges upon a reciprocal definition of the word and the written character. The collapse of the linguistic and grammatological categories leads Gelb to project the graphic transcription of sounds back onto the language itself, proclaiming, as did many linguists before him, that the Chinese language is "preponderantly monosyllabic" (ibid., p. 110). Strictly speaking, language itself cannot be monosyllabic, and only the written transcriptions of its syllables can be characterized as such. Gelb's misunderstanding is a manifestation of the play of supplementarity between writing and speech. For a critique of the problematic relationship between the $z i$ or $c i$ (Chinese written character) and the concept of the word, see Liu, The Clash of Empires, pp. 203-9.

76. The assumption is that one written sign can stand for a group of words all related in meaning and, with the emergence of phonetization, for words similar in sound but with no relation to meaning, as in the rebus. See $S W$, p. 106. 
grammatology was to bring alphabetical writing and nonalphabetical writing systems into the same unifying, noncontradictory space of the logos. For instance, the Chinese written character makes sense only insofar as it corresponds phonetically to one or more words in the language, but this representation is based a priori on Gelb's belief that "the original object of writing is the creation of symbols which stand for words of the language" (SW, p. 97). The move in the direction of total phonetic inscription caused Gelb's systems of writing to sink deeper into the logocentric quagmire, until Derrida came along and guided the study of grammatology in a new direction. ${ }^{77}$ From the very start, Derrida saw the logocentric concept of alphabetical writing as the bearer of the "most original and powerful ethnocentrism" in Western philosophy. ${ }^{78} \mathrm{He}$, therefore, took it upon himself to launch a rigorous program of reading and critiquing the entire philosophical scaffolding of the West, which was said to rest upon a metaphysics of phonetic writing underlying all forms of binarisms. The arrival of Printed English on the wings of biocybernetic developments, however, has presented a very novel situation to the grammatologist and to his critique of Western metaphysics. By eluding phonocentrism, the metaphysics of Printed English has simultaneously eluded Derrida's critical endeavor in profound ways.

This is because Printed English has thoroughly dissolved the binary opposition between writing and speech in advance of poststructuralism. This powerful imperial technology exists as a statistical system of ideographic symbols that presupposes a fundamental distinction between Printed English and written English at the expense of the third term: spoken language. When McLuhan's evolutionary view of primitive pictographic thinking and the phonetic alphabet no longer obtains in the age of information technology, it is odd that in the humanistic disciplines, the overwhelming tendency is still to hold onto the opposition between written English and spoken language at the expense of the digital invention: Printed English. Scholars of literature are so used to working with the inherited metaphysical properties of speech and writing that even in our most deconstructive moments we have not been able to take the mathematical construct of Printed English seriously. But sooner or later this cybernetic construct will force us to reconsider in fundamental ways the technology of ideographic English, future theories of translation, and perhaps literary theory itself.

Printed English, then, is a postphonetic system of alphanumerical symbols that offers an original and universal code for global communication as well as imperial rule. I believe scientists like Shannon and Turing would not

77. Derrida acknowledges Gelb's pioneering work in one of his footnotes. See Derrida, Of Grammatology, p. 323 n. 4 .

78. Ibid., p. 3 . 
subsume Printed English under a blanket notion of generalized writing for several reasons: First, written English presumes an obsolete binary opposition between speech and writing that, as I have demonstrated in the foregoing analysis of Shannon's discrete and continuous signals, no longer has any valence in biocybernetic systems in which the binary of 1 and $o$ (on and off) reigns supreme in a new game of metaphysical thinking. Secondly, the machine's marking of typographical surfaces with printed symbols evinces a technological property that ought not to be confused with signatures, handwriting, calligraphy, and other similar signs of inscription any more than it can be collapsed with orality or phonic production..$^{79}$ Finally, Printed English has achieved a statistical ontology through the invention of iSpace, the twenty-seventh letter, and discrete spacing mechanisms à la Joyce, Ogden, Shannon, Mallarmé, Turing, and others, which is unmatched by any written systems to date. With Printed English, and with the eruption of discrete symbols upon the scene of inscription in the biocybernetic era, the ideographical movement of the phonetic alphabet has come full circle.

79. Thomas Levin's fascinating study of the invention of synthetic sound in early cinema suggests that phonic productions are derivative of statistical engineering as opposed to sound reproduction with gramophone. See Thomas Y. Levin, “'Tones from out of Nowhere': Rudolph Pfenninger and the Archaeology of Synthetic Sound," Grey Room, no. 12 (Summer 2003): 32-79. 